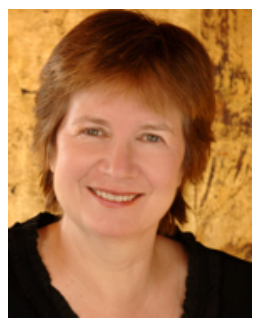

\title{
TOO HOT TO HANDLE: CLIMATE CHANGE AND AGRICULTURAL WATER USE
}

\author{
Denise Fort
}

Professor of Law at the University of New Mexico School of Law and Director of the School's Utton Center, United States

The world faces enormous challenges in responding to looming crises in food and water. Responding to this challenge will require flexibility; such flexibility may be impeded by legal institutions. This paper looks at the western United States and discusses the role of irrigated agriculture in that region. Because of climate change, a growing population, declining groundwater, the need to protect ecosystems and other conflicts, the author suggests that all water uses, including long-standing agricultural water rights, need to be examined in light of these changes. Legal systems have tended to serve the status quo, but perhaps the law can help facilitate this re-examination.

\section{Introduction}

Irrigated agriculture is by far the largest sector of water use in the western United States, consuming about 85 per cent of total water consumption. Agriculture was encouraged by the federal government as part of the inducement for migration to the west ${ }^{1}$ in the 19th and early 20th centuries. Despite a huge growth in population, the ascendancy of new economies and the high costs associated with new water supplies, agricultural uses continue to dominate water use. This is coupled with the rising demand for water from urban areas and has resulted in the destruction of natural systems, with natural systems becoming degraded and extinction awaiting many species. ${ }^{2}$ Rising water demands also result in higher energy costs for new supplies as pipelines and groundwater pumping add to the carbon profile of water. Depleted groundwater basins necessitate extreme measures to secure water. Agricultural water use has been affected by the new uses of water, but the private property rights that were vested in the last century largely insulate agriculture from the dire choices that affect other sectors. As a beneficiary of the status quo, agriculture has resisted changes to water policies. ${ }^{3}$

Climate change will bring about new precipitation patterns in the west, the increased use of water for irrigation and landscaping due to warmer temperatures, and a host of challenges for humans and other species in this arid land. Under a changing climate, the questions raised by irrigation in an arid region are sharpened. In this paper I ask why do agricultural uses continue to predominate and how should federal and state policy makers respond to the environmental challenges posed by climate change.

The underlying question is how society can adapt to these changing circumstances. With respect to water use - as with many other aspects of how we live - it is imperative that the law facilitate a change in the trajectory that has brought us to the point of profound environmental crisis and support adaptation to a more sustainable future. The dedication of water to agriculture in

\footnotetext{
I will use 'west' to refer to the western United States throughout this article.

2 J E Deacon et al, 'Fueling Population Growth in Las Vegas: How Large-Scale Groundwater Withdrawal Could Burn Regional Biodiversity' (2007) 57(8) BioScience 688; C Nilsson et al, 'Ecological Forecasting and the Urbanization of Stream Ecosystems: Challenges for Economists, Hydrologists, Geomorphologists, and Ecologists' (2003) 6 Ecosystems 659.

3 R D Benson, 'Maintaining the Status Quo: Protecting Established Water Uses in the Pacific Northwest, Despite the Rules of Prior Appropriation' (1998) 28(4) Environmental Law 881; D A Tarlock, 'The Future of Prior Appropriation in the New West' (2001) 41(4) Natural Resources Journal 769.
} 
the arid west illustrates the need for society to be able to fully review and potentially make sharp corrections to decisions made by prior generations.

The legal framework for water decision-making in the United States is famously complex. Modern societies have changed communication technologies, invented new drugs and new means of transportation and are on the edge of exciting breakthroughs in several areas of science. Were these areas governed by the institutions that control water use, it is dubious whether the telephone would have been adopted, much less the Internet. Our legal system favours the status quo, and agricultural users hold the oldest and most substantial water rights. Further, the pervasive role of government in water has also perpetuated the status quo. As we consider the role of law in the American West, we find that it has slowed the responsiveness of water management to changed circumstances rather than supporting change.

I will sketch the role of irrigated agriculture and raise questions that might be pertinent to policymakers in considering the role of irrigated agriculture in the future. The topic, 'irrigated agriculture', obviously is one that generates conflict and puts the issues of governance squarely before us, because multiple entities have a stake in these decisions.

The basic framework for water management in the western United States has been described by many authors and will not be repeated here except to note that, although states have legal control over the allocation of water, federal policy is significant in shaping the uses of water in ways that I will describe below. I will focus on federal policy issues because it is too daunting to discuss decision-making in each of the western states.

\section{Water use in the western United States}

The context of water use in the west is one that has been shaped by the geography and history of the region. In the last few decades, changes in the region's population and economy have started to be reflected in water transfers and other approaches to meeting urban needs.

Human habitation of this region has always been tied to water. The Hohokam civilization, located in what is now central Arizona, developed highly sophisticated water collection systems to support its growth more than a thousand years ago. ${ }^{4}$ Continued settlement of the west depended on the diversion of water for irrigated agriculture. ${ }^{5}$ Construction of reservoirs enables storage and control of additional water. Conveyance systems involving canals, pumps, tunnels and other structures allow for the transport of water across long distances, even between river basins. Improved pumps make it possible to tap into groundwater aquifers, sometimes at considerable depths. Indeed, '[m]ore than a century of reclamation has remade the map of the west, replumbing nearly every river with massive reservoirs, diversions, irrigation systems, hydroelectric plants, and flood-control structures'. ${ }^{6}$

Agriculture, as discussed above, is the largest consumer of western water. For example, agriculture accounts for more than 80 per cent of water used in California's Sacramento-San Joaquin Delta. ${ }^{7}$ Federal support of water storage and distribution enabled larger populations to inhabit the region and permitted agriculture far from rivers and streams. ${ }^{8}$ State and federal legal regimes protect these uses of water and make transfers difficult.

\footnotetext{
${ }^{4}$ Tempe History Museum, The Hohokam (30 March 2001) <http://www.tempe.gov/museum/Tempe_history/basics/hohokam.htm>.

${ }^{5}$ Western Governors' Association, Water needs and strategies for a sustainable future (2006)

<http://www.westgov.org/wga/publicat/Water06.pdf>.

${ }^{6}$ P H Gleick, 'Roadmap for Sustainable Water Resources (2010) 107(50) Proceedings of the National Academy of Sciences 21300.

${ }^{7} \mathrm{H}$ Cooley et al, More with Less: Agricultural Water Conservation and Efficiency in California: A Special Focus on the Delta (Pacific Institute, 2008).

${ }^{8}$ D Worster, Rivers of empire: Water, aridity, and the growth of the American west (Oxford University Press, 1985).
} 
The role of Native American tribes in using and owning water has been a contentious aspect of western water. The legal basis for tribal ownership of water was established under the reserved rights doctrine, but the adjudication of tribal water has proceeded at a glacial pace. For example, in New Mexico the adjudication process for the state's rivers began more than 30 years ago, but water rights for the majority of the state's 22 Indian Pueblos, Tribes and Nations have yet to be quantified (New Mexico Office of the State Engineer 2011). ${ }^{9}$ Further, because non-Indian communities grew and utilized water without regard to tribal water rights, settlements of tribal water rights claims typically provide protection of existing water uses. Thus, tribes will receive some portion of rights that they have claimed but in the context of settlements that provide benefits to entire regions. This results in high costs for the federal government. Tribes also have water rights through treaties and other legal bases. These rights have been important in the Pacific Northwest where dams and other water projects have affected fish species.

Municipal and industrial water users have the ability to pay for water and most of the transfers in western water are from agricultural uses to these other uses. These sectors are also making use of water conservation and new technologies to reuse water. One particular industrial demand for water has drawn attention in recent years. The west is abundant with energy sources, such as uranium, coal, oil and natural gas, and new energy sources such as coal-bed methane and shale gas are being ferociously developed across the west. The majority of western mining techniques use substantial quantities of water, and can contaminate surface and groundwater. The United States Geological Survey estimated that water use for mining in 2000 was approximately 3920 000 acre-feet per year. ${ }^{10}$ The burning of coal for power comes at a high price in terms of water use. Even low-carbon sources, such as nuclear and concentrated solar, have high water profiles.

Western waterways and riparian ecosystems have been destroyed by diversions of water, and most of these diversions are for agricultural purposes. Destruction of ecosystems, species loss and accelerating habitat degradation from climate change and recent, prolonged droughts in the western United States means that water must be found and restored to rivers if species are to be protected from extinction. Recreationalists want water in rivers for fishing and boating, and even cities are discovering that waterways can be tourist attractions. ${ }^{11}$

National priorities that have emerged in recent decades have shifted the balance of state and federal interests in western water management. State water policy encourages development and use of available resources by awarding water rights for those uses that are administered and protected under state law. In contrast, federal water agencies - while still emphasizing support for traditional water users - have begun to include management and implementation of other national priorities, such as water quality regulation, wetlands management and endangered species protection. The federal Endangered Species Act of $1973(E S A)^{12}$ provides protection for aquatic species, which has affected water management on major western river systems. The ESA prohibits federal actions that would jeopardize the continued existence of protected plant and animal species. As another example, the federal Clean Water Act (CWA $)^{13}$ established a national program regulating the discharge of pollutants into water from point sources. States generally implement the program, but are closely regulated by federal laws and regulations. Thus, the federal mandate to protect water quality and aquatic habitats for protected species can tip the scales from state to federal control over water resources.

In summary, water uses continue to be dominated by agriculture but a host of other uses increasingly compete with this traditional use. The economics of agriculture are relevant, and that is addressed next.

\footnotetext{
${ }^{9}$ New Mexico Office of the State Engineer, Native American Water Issues <http://www.ose.state.nm.us/special_projects_nawrp.html>.

${ }^{10}$ United States Geological Survey, Mining water use (2011) <http: / /ga.water.usgs.gov/edu/wumi.html>.

${ }^{11} \mathrm{C}$ H Bonham, 'Perspectives from the Field: A Review of Western Instream Flow Issues and Recommendations for a New Water Future' (2006) 35(4) Environmental Law 1205, 1211.

${ }^{12}$ Endangered Species Act of 1973, 16 USC $\$ 1531$ et seq (1973).

${ }^{13}$ Clean Water Act, § 402(p) 33 USC § 1251 (2002).
} 


\section{Irrigation water use in the United States and the world}

A comparison of total water use for irrigation in the United States and worldwide is shown in Table 1.

Table 1: Irrigation water use in the United States and the world

\begin{tabular}{|l|c|c|c|}
\hline & $\begin{array}{l}\text { Total Withdrawals } \\
\text { for Irrigation, in } \\
\text { MAF/year }\end{array}$ & $\begin{array}{l}\text { Surface Water With- } \\
\text { drawals for Irrigation, in } \\
\text { MAF/year }\end{array}$ & $\begin{array}{l}\text { Groundwater With- } \\
\text { drawals for Irrigation, in } \\
\text { MAF/year }\end{array}$ \\
\hline United States $^{14}$ & 144 & 84 & 60 \\
\hline Worldwide & $1,908^{15}$ & $1,355^{16}$ & $343^{15}$ \\
\hline
\end{tabular}

Agriculture is about 1.2 per cent of the Gross Domestic Product (GDP) of the United States. Because of geographical diversity, the value of crops grown with irrigation water varies widely, but nationally about half of all crop value comes from the 16 per cent of cropland that is irrigated. ${ }^{17}$ In United States' agriculture, consolidation has led to larger operations that consume a high percentage of water for irrigation: the largest 10 per cent of all irrigated farms in the west use 50 per cent of all irrigation water. ${ }^{18}$

California, with its high value vegetables, fruits and nuts, illustrates one end of the economic continuum; intermountain states that grow alfalfa and other feed crops illustrate the other. The California agricultural sector has the fifth largest exports of agricultural products in world, but agriculture nonetheless provides only two per cent of the state's GDP. In other western states, agriculture occupies a similar position, in the range of 0.8 per cent (Texas) to 2.5 per cent (Oregon). ${ }^{19}$

The employment in agriculture is grouped by the United States Census Bureau with other occupations, but averages around one to two per cent of the western population. ${ }^{20}$

On their face, these data confront us with a number of questions concerning the fundamental public interest in the allocation of scarce water. Why does agriculture continue to occupy such a high percentage of the west's water use if the economic return is relatively small compared to other uses that all require water? What societal and institutional forces are at play that perpetuate western irrigated agriculture as a major consumer of water? The contribution of irrigated lands to food stocks, fibre, fuel and other consumer products is significant; what would a reallocation of water mean to these uses? In answering all of these questions, the legal status quo emerges as perhaps the most significant factor.

As lawyers, we look first to the nature of western property rights allocations in understanding property distributions. Under state water doctrines, rights in water are comparable to conventional property interests. Thus, a water right acquired in the 1890 s will continue to attach to an irrigated farm unless it is severed from the property or is lost through disuse. The picture obviously is not one of stasis. In the American west, the discussion can be glimpsed in the debates

\footnotetext{
14 J F Kenny et al, 'Estimated Use of Water in the United States in 2005' (US Geological Survey Circular 1344, United States Geological Survey, 2009) Table 72005 data.

${ }^{15}$ D U Seckler et al, 'World Water Demand and Supply, 1990 to 2025: Scenarios and Issues' (Research Report 19, International Water Management Institute, 1998). The worldwide number includes United States estimated irrigation withdrawal rate of $159 \mathrm{MAF} /$ year from 1990 data.

${ }^{16}$ World Water Assessment Programme, 'The United Nations World Water Development Report 3: Water in a Changing World' (UNESCO Publishing, 2009).

17 United States Department of Agriculture. 'Western irrigated agriculture (2004) <http://www.ers.usda.gov/Data/WesternIrrigation/>.

${ }^{18}$ United States Department of Agriculture, 'Irrigation, Water Conservation, and Farm Size in the Western United States' (2004) <http://www.ers.usda.gov/AmberWaves/ June04/findings/IrrigationWestern.htm>.

${ }^{19}$ EconPost, 'Agriculture Sector Top States by Percentage of State Economy' (2010) $<$ http: / /econpost.com/industry/agriculture-sector-top-states-percentage-state-economy/>.

${ }^{20}$ United States Census Bureau, Population Distribution and Change 2000-2010 (Washington, DC, US Department of Commerce, 2011).
} 
over water transfers to urban uses. In a relatively short time, water transfers, water banks and forbearance arrangements have become less controversial than they were 20 years ago. Nonetheless the transfer of water rights remains complex and costly. ${ }^{21}$

Another reason for the continuing agricultural share of water presents a paradox: while water rights are mostly held privately, a vast publicly built infrastructure supports the distribution and use of this water. Reservoirs, pipelines, irrigation works and diversions were often built by the federal government, or by state and substate units. Thus, governments are ongoing participants in agricultural water use. The agencies responsible for maintenance and operation of these facilities become dependent on the status quo for their own existence.

The federal government has protected and maintained western agriculture through a number of policies. The support of selected crops under the federal Farm Bill can be a critical determinant of water use. ${ }^{22}$ It is questionable whether some subsidized crops in certain regions would even be grown if no such subsidies were available. ${ }^{23}$ For example, a Texas study of the impact of the Farm Bill on agricultural practices in lands overlying the Edwards Aquifer concluded that, without the subsidies, some percentage of farms would revert from subsidised grain crops to crops such as vegetables and hay. It is noteworthy that the effect of this shift in crop types might result in an overall increase in water used for irrigation because the non-subsidised crops tend to be more water intensive than traditional subsidised grain crops. Irrigated acreage also is affected when federal farm policy includes set-aside requirements for non-cropping of land. ${ }^{24}$ Federal agricultural policy shapes land and water use, environmental quality, and ecosystem diversity. ${ }^{25}$

Exemptions from environmental laws have allowed agriculture to continue practices that would have required investment in pollution control technologies by any other industry. The Clean Water Act, for example, exempts return flows from irrigation that otherwise would be subject to pollution controls. ${ }^{26}$ Return flows are often contaminated by chemicals or sediments and therefore represent effluent emissions that would otherwise require licensing and treatment. Discussions of legal accountability for water use or contamination are generally muted when compared to equivalent discussions for other industrial water uses.

Most policy discussion about irrigated agriculture revolves around how to increase the efficiency of agricultural water use. Efficiency is a means to keep agricultural production while at the same time 'creating' water that can be transferred to other uses, which typically would be municipal. Water pricing, which may occur through water rates, also can bring about conservation. ${ }^{27}$ The agricultural sector tends to respond to pricing more than other sectors especially in regions where water is already scarce. ${ }^{28}$ Because agriculture uses the largest portion of water in the west, even small gains in conservation and efficiency driven by pricing will have the largest impact on overall water supplies.

The federal relationship to irrigation is in the process of change. The paradigm of the last century was that of federal subsidies for the construction of storage and delivery of water for

\footnotetext{
${ }^{21}$ R Howitt and K Hansen, 'The Evolving Western Water Markets' (2005) Choices: The Magazine of Food, Farm, and Resource Issues <http://www.choicesmagazine.org/ 2005-1/environment/2005-1-12.htm>.

${ }^{22} \mathrm{G}$ E Frisvold, P N Wilson and G Needham, 'Implications of Federal Farm Policy and State Regulation on Agricultural Water Use' in Arizona Water Policy: Management Innovations in an Urbanizing, Arid Region (Resources for the Future Press, 2006).

${ }^{23}$ G B Frisvold, ‘How Federal Farm Programs Affect Water Use, Quality, and Allocation Among Sectors' (2004) 40(W12S05) Water Resources Research, 3 <doi:10.1029/2003WR002753)>

${ }^{24}$ M E Chowdhury et al, 'Effect of USDA Commodity Program on Annual Pumpage from the Edwards Aquifer' (1996) 106 Water Resources Update, Universities Council on Water Resources 72.

${ }^{25}$ United States Department of Agriculture, ‘Agricultural water enhancement program’ (2011) <http://www.nrcs.usda.gov/programs/awep>.

${ }^{26}$ Clean Water Act, § 502(14), 33 USC § 1362 (2002).

${ }^{27}$ R C Johansson et al, 'Pricing Irrigation Water: A Review of Theory and Practice' (2002) 4 Water Policy 173.

${ }^{28}$ S M Olmstead, The Economics of Managing Scarce Water Resources (2010) 4(2) Review of Environmental Economics and Policy 179.
} 
irrigated agriculture. The federal Bureau of Reclamation stores and delivers much of the water used by irrigators in the west. The pressures exerted by the familiar elements of population growth, involvement of new stakeholders and national policies to protect the environment have led to a changed federal role that is more focused on serving multiple functions. Most importantly, new water projects (and subsidies) are much more likely than was traditionally the case to serve municipal and industrial purposes. Thus, the federal government continues to serve irrigators, but now acknowledges other interests, especially with respect to species protection.

The social benefits of subsidies from agriculture affect the continuing dedication of water to irrigated agriculture. Consumers in the United States pay a relatively small percentage of their disposable income for food. There are very strong market and political forces in place as Americans have come to expect low food prices. Low food prices and the low percentage that agriculture contributes to the United States GDP are both the result of changes and innovation in farming over the past 100 years. Early 20th century agriculture was labour intensive, taking place on a large number of small, diversified farms in rural areas where more than half of the United States population lived. It employed close to half of the United States workforce. In contrast, agriculture in the $21^{\text {st }}$ century is concentrated on a small number of large, specialised farms in rural areas where less than a fourth of the United States population live, and employs a small fraction of United States workers. The increased efficiency of agriculture has contributed greatly to the overall growth of the United States economy, allowing consumers to spend smaller portions of their income on food and freeing a large share of the population to enter nonagriculture occupations, spurring economic growth into a vast array of markets. ${ }^{29}$ In this way, focusing on the shrinking contribution of agriculture to GDP ignores the overall positive impact that increasing efficiencies in food output has on the United States economy.

These observations about contemporary water use in the west raise the question whether the existing water rights arrangements in the western United States meet the public interest, and what the implications of change would be for water law reform.

\section{Questions about water and food: the societal perspective}

The western United States exports food to a global market. Australia is also a food exporter: A $\$ 23.3$ billion in 2006-2007. ${ }^{30}$ Is it possible that exporting food from arid lands might be bad policy?

This is a difficult discussion to have. The public discourse in the west is emotional, raucous, rancorous, and unlikely to change anyone's mind. Agricultural subsidies have been sacrosanct in United States politics for generations. ${ }^{31}$

While 'Big Ag' has a big footprint in Washington, DC, local arguments about water and agriculture often can involve a very different set of interests aligned in support of irrigation or the political interests of the farming status quo. In New Mexico, the culture of agriculture is respected and valued across the state, especially in the Hispanic north. A new emphasis on local food, a movement that seems to have permeated the entire nation, brings additional supporters of agriculture to the debates. Very few westerners, except perhaps those who are in the housing development business, would rather see subdivisions than irrigated fields. Many believe that agriculture is a barrier against sprawl. ${ }^{32}$

\footnotetext{
${ }^{29} \mathrm{C}$ Dimitri et al, 'The $20^{\text {th }}$ Century Transformation of US Agricultural Water Conservation and Efficiency in California: A Special Focus on the Delta' (2005) Pacific Institute: Reports.

${ }^{30}$ Australian Department of Foreign Affairs and Trade, 'About Australia' (2008)

<http://www.dfat.gov.au/facts/foodindustry.html>

${ }^{31}$ R Nixon, 'In Battle Over Subsidies, Some Farmers Say No', New York Times (New York) 23 July 2011 <http://www.nytimes.com/2011/06/23/us/23crop.html?ref=farmbillus>.

321000 Friends of Oregon, 'Protecting Oregon's Core Industries: Farming, Forestry, \& Ranching' (2010)

<http://www. friends.org/healthy-rural-economies/farmland>; C O'Connor, 'Boulder County Agriculture Division Helps Keep Urban Sprawl at Bay’ Denver Post (Denver) 3 September 2011, <http://www.denverpost.com/news/ci_18817843>.
} 
Attitudes towards agricultural water use in the west might be described as mixed: there is strong support for farmers, but also popular support for rivers, for population growth in cities and for new economic activities. While agriculture does pretty well in its political battles over water against environmentalists, it is a poor match in water competition against cities because of the much higher prices that cities will pay for water and the political strength of urban voters. Transfers of water, water banks, funding of conservation and like measures facilitate the movement of water to urban uses. The environment has not fared as well in this contest over water because neither state fishery agencies nor federal agencies acting under the ESA have the level of funds that cities can command.

\section{How to think about water and food: questions about the govern- ance framework}

Climate change is one factor that will push the United States into making decisions about agriculture in the west. The near paralysis of national political decision-making, in which the Congress appears to have reached impasses in most areas of national importance, ought not be replicated in western water management. If decisions are not made through political leadership, they will have to be made by water administrators and courts, applying legal regimes that are not widely understood and may not be endorsed by broader publics.

Does anyone envy the task of water administrators? These issues pose serious difficulties for water administrators; the challenges can only increase. The expectation is that water rights will translate into water - at least when a drought ends. Reservoirs run low, but cities plan ahead and continue to deliver water to customers. Farmers receive less water - and perhaps receive federal funding for drought assistance. A shift in climate, however, means that no one can assume that a reservoir will recover. If agriculture is going to continue in the west, it is likely that new storage will be required. Cities will ask for money for water reuse, desalinisation and, perhaps, 'new' supplies, piped in from groundwater basins or agricultural transfers. If fish are to be protected, water will need to be purchased and dedicated to in-stream purposes. It is through such budget decisions that the major public decisions will be made, whether or not the required tradeoffs are measured in a deliberative process.

\section{How should these questions be addressed?}

The western United States does not have an adequate structure for decision making over water. The problem is not the lack of a market, or at least that is not the only problem. The problem is that water decision-making remains largely the province of those with 'skin in the game'; that is, those who own water or are seeking to acquire it. Thus state administrative proceedings typically involve representatives of rights holders. The primary move for new water comes from cities, where populations are soaring. Municipal governments seek funding for projects after population growth has occurred, or seek it from Congressional representatives, in the classic dynamic of the 'iron triangle' where decision-making occurs among a very few parties.

But everyone, rights holder or not, has something at stake in how the nation confronts the constrained and stressful water future. For water managers and decision-makers, water planning is underpinned by the assumption that prior appropriation cannot be changed. A few professors would argue that it should be jettisoned; but this debate has yet to gain legitimacy in political settings.

Another foundation of western water law is the compacts that divide the water among states in a basin. Most compacts date to a time when populations were much smaller and distributed differently than they are now, when river flows were not well understood, before tribal water rights were recognized, before a time when the ecological benefits of rivers were understood, and before climate change was envisioned. Nonetheless, the compacts provide another element 
of the architecture of water governance. Again, the assumption is that compacts cannot be changed.

In the western United States, we need to assist water reform by creativity and a commitment to moulding new institutions that better serve this century. I think that those of us in academia have the opportunity and the obligation to articulate the fundamental alternatives that can be a spur to reform.

In that spirit, let us turn to irrigated agriculture in arid regions.

The nation needs to re-examine the depth of its commitment to prioritising water for irrigated agriculture given the changed circumstances of greater population, ecosystem destruction, and climate change. It needs to consider the value and efficiency of food production provided by these practices compared to other water uses, and determine whether exporting water in the form of food is a beneficial practice for the region and the world. By implication this involves questioning the legal doctrines of water ownership, and the institutional and administrative structures for water administration.

Major water decisions are made by elected bodies, but with participation by very few people. Oddly enough, the National Environmental Policy Act (NEPA) ${ }^{33}$ does not apply to actions by the Congress, although it does when agency spending is carried out. To have public participation in these momentous questions, one would want to have information about these trends made available, along with the costs and benefits of business as usual, and the costs of benefits of alternative uses of water, including for ecosystem services. In Australia's continuing debate over water reallocation in the Murray-Darling river basin we see an example of how these questions could be brought forward to a broader public; community outreach and engagement from the public are central features of the administration of the Murray-Darling Basin Authority. ${ }^{34}$ A necessary law reform may be to ensure broader public participation and a more robust contest over water management as a means to trigger other legal and institutional reforms that will increase flexibility and reassert the public interest in what is overtly a public good.

\section{Implications}

The use of water in arid regions to grow crops for export touches on a universe of important concerns; the world has neither fresh water nor food in abundance. Too many people are hungry now and many more face hunger in the future. ${ }^{35}$ Food policy, international development and world security seem far afield from the typical concerns of state water policy but this is an instance where the local is global. Hence compelling questions must be considered:

- How should the United States treat agricultural subsidies, especially in light of their effect on agriculture in developing nations?

- Is globalisation of food, in the form of agricultural exports, sustainable?

- Is the practice of foreign nations purchasing agricultural land and facilities in other nations (China, mid-Eastern nations) beneficial? How does that change the degree of protection to be given to ecosystems within the food-producing nation?

- What does governance mean at a large scale?

Congressional involvement in water decision-making has largely been immune from public debate of the sort seen, for example, over health care. Water deals are made, the 'right' people involved and public participation - as typically understood - does not occur. I have proposed that taking Congressional funding out of western water would help democratic processes, by requiring

\footnotetext{
${ }^{33}$ National Environmental Policy Act, 42 USC $\S 4321$ et seq (1970).

${ }^{34}$ See <www.mdba.gov.au>; <http://www.mdba.gov.au/communities/latest-news>.

${ }^{35}$ Food and Agriculture Organization of the United Nations 'How To Feed the World in 2050'

(2009).<http://www.fao.org/fileadmin/templates/wsfs/docs/expert_paper/ How_to_Feed_the_World_in_2050.pdf>.
} 
local entities to fund their own projects. At a national scale, the framing of agricultural policy and trade policy occurs with even less public participation.

These far reaching implications are relevant, but also informed by the practices in the western United States. Here I have asserted that permanent hegemony over water in the west by western agriculture does not mirror the situation for most property in our fast-moving economy. Water law and the structure of water governance have held back changes in water management, arguably protecting one form of resource use against the forces of capitalism and competing demands for that resource, and providing some stability to farmers, but also discouraging efficiency and innovation in the management of water.

Irrigation in arid regions has been 'off limits' to reasoned public discussion for too long. Climate change and the necessity to adapt, provide an unsought opportunity to ask whether the decisions of the last 150 years will serve society in the future. By using the law to provide for public involvement, by demonstrating that the settled precepts of water law can be changed, and by utilizing science, we can play a role in providing a better transition to a difficult future. 